\title{
Luento-opetuksen kehittäminen käytännönläheisillä menetelmillä
}

\author{
Jouni Kekäle tarkastelee artikkelissaan käytännönläheisiä keinoja, \\ joiden avulla voidaan ylittää eräitä perinteisen luento-opetuksen ongelmia. \\ Artikkeli pohjautuu kirjoittajan luento-opetuksen kehittämistä \\ tarkastelevaan julkaisuun, jossa esitellään ulkomailla ja Suomessa - mm. \\ Joensuun yliopiston pedagogisen kehittämishankkeen yhteydessä - \\ koeteltuja menetelmiä.
}

Luennoinnilla on opetusmenetelmänä vuosisataiset Perinteet. Näiden vuosisatojen kuluessa yhteiskunta, ihmisten arvot ja tietokäsitykset ovat kuitenkin muuttuneet perinpohjaisesti. Tiedon määrä on kasvanut räjähdysmäisesti, minkä vuoksi oppiminen ja asioiden hallitseminen edellyttää yhä enemmän tiedon aktiivista valikoimista, pohdiskelua ja prosessointia. Kun yliopistoille suunnatut resurssit ovat lisäksi viime vuosina merkittävästi vähentyneet, on nyt hyvin perusteltua uudelleenarvioida opetuskäytäntöä. Varsinkin Yhdysvalloissa, Englannissa ja Australiassa on yliopistojen kehittämiskeskuksissa tuotettu 1980-luvulta lähtien opettajien käyttöön runsaasti käytännönläheisiä ideoita ja tietoa erilaisista opetuskokeiluista. Tätä materiaalia opettajat voivat soveltaa kehittäessään opetustaan. Mainittua aineistoa on koottu myös korkeakoulupedagogiikan perusmateriaali -projektin julkaisuihin (Kekäle 1994; Kuittinen 1994; Karjalainen \& Kemppainen 1994), joista ensin mainittuun tämä artikkeli pohjautuu.

\section{Oppiminen on aktiivista toimintaa}

Em. julkaisuissa lähtökohtana oli ns. konstruktiivinen oppimiskäsitys. Sen pohjalta oppiminen nähdään aktiivisena tietorakenteiden rakentamisena, jossa uuden oppiminen pohjaa aiemmin opittuun (ks. esim. Lonka 1991a). Oppija konstruoi, rakentaa kuvaa ulkoisesta maailmasta ja etsii selityksiä sen eri ilmiöille. Tiedolliset rakenteet ja sisäiset mallit syntyvät, jäsentyvät ja rikastuvat osana kehämaista kehitysprosessia, jossa uuden oppiminen aina perustuu aiemmalle. Todellinen oppiminen ei ole faktojen tallentamista, vaan oppijan sisäistä, henkilökohtaista ja päämäärähakuista toimintaa (Lonka 1991a). Opetuksen tehtävä on käynnistää ja ohjata opiskelijoiden aktiivista henkistä työskentelyä (Marton ym. 1989, 127; Engeström 1991, 15). Hyvin suunniteltu luento edellyttää kuulijoilta nimenomaan monipuolista ja intensiivistä henkistä toimintaa (Engeström 1991, 121-123). Vaikka tiedon rakentaminen onkin yksilöllinen tapahtuma, ei kuitenkaan välttämättä ole täysin samantekevää, niitä ihminen oppii tai minkälaista maailmankuvaa hän rakentaa. Fyysisen todellisuuden mahdollisuudet ja rajoitukset sekä sosiaalisen toiminnan suhteellisen vakiintuneet ehdot (esim. tavat, lait, kulttuuri) rajaavat ja määrittelevät, millainen toiminta suhteessa muihin ihmisiin on kulloinkin suotavaa, mahdollista ja tuloksellista (Lehtinen ym. 1990, 28).

\section{Opetuksen kehittäminen käytännönläheisillä menetelmillä}

Julkaistessani (Kekäle 1994) keskitytään käytännöllisiin ja opetusmenetelmällisiin ohjeisiin. Tässä lähestymistavassa on riskinä, että kiinnitetään liikaa huomiota opetuksen ja opetusmenetelmän ulkoiseen puoleen, eli siihen näkyvään vuorovaikutukseen, joka on havaittavissa välittömästi kun astutaan opetustilaan. Esimerkiksi Engeström (1991, 120) korostaa opetusmenetelmän sisäisen puolen merkitystä: olennaisinta opetuksessa on se, minkälaiseen henkiseen oppimistyöskentelyyn opetuksella kussakin vaiheessa pyritään. Engeströmin ajatuksena on, että tietosisältö on opetuksen ydin. Jos opetusmuodot ja muodolliset ominaisuudet nousevat pääasiaksi, saatetaan helposti joutua tilanteeseen, jossa ei enää pyri n opettamaan opiskelijoille jotakin uutta, vaan pyritään pikemminkin viihdyttämään heitä tai turvaamaan riittävä vaihtelu ja ulkoinen aktiivisuus (Engeström 1991, 102). Esimerkiksi ryhmätöistä tai keskusteluista ei välttämättä ole hyötyä asian oppimisen kannalta, mikäli ne eivät pureudu olennaiseen asiaan tai ne eivät stimuloi asiaan liittyvää aktiivista pohdintaa.

Opetuksen ulkoisia puitteita ei kuitenkaan tule vähätelläkään. Vaihtelua ja aktiivisuutta tarvitaan, mutta yksin ne ovat riittämättömiä oppimisen ehtoja (Engeström 1991, 121-123). Mikäli toisaalta oppimisen ulkoinen puoli tai puitteet eivät ole kunnossa tai ne ovat epäsuotuisia, vaikeutetaan tai jopa estetään tällöin tarpeettomasti oppimista. Monet julkaisussani (Kekäle 1994) sekä tässä artikkelissa esitetyt kehittämisideat kohdistuvat juuri oppimisedellytysten turvaamiseen luentotilanteissa; olennaisen asian tunnistaminen riippuu mm. oppiaineesta ja on lähinnä opettajan asiantuntemuksen varassa. Opetusta voidaan kuitenkin kehittää myös käytännönläheisten 
menetelmien kautta. Tätä opetuksen kehittämisen lähestymistapaa voidaan perustella ainakin seuraavilla seikoilla:

Ensinnäkin opetusmenetelmällisillä ratkaisuilla voidaan osaltaan tukea aktiivista oppimista. Bonwell ja Eison (1991, 2) määrittelevät aktiiviseksi oppimiseksi väljästi ottaen minkä tahansa toiminnan, mikä edellyttää opiskelijoilta (opittavaan alueeseen liittyvien) asioiden tekemistä tai työstämistä sekä niiden aktiivista pohtimista (ks. myös Lonka \& Lonka 1991).

Luennolla istuminen ei sinänsä viritä aktiivista oppimista, sillä opiskelijan tarkkaavaisuus ja ajatukset voivat suuntautua johonkin myös muuhun kuin käsiteltävään asiaan (esim. unelmointiin). Korkeampaa aktiivisuuden astetta edustaisi opiskelijan aktiivinen, luennoitavaa asiaa jäsentävä ja tiivistävä, pohdiskeleva muistiinpanojen teko (ei siis kuitenkaan luentokalvojen mekaaninen kopiointi). Opiskelijoiden osallistumista voidaan tästä yleensä vieläkin lisätä, mikäli opettaja onnistuu herättämään kysymyksiä ja keskustelua ja auttamaan täten opiskelijoita esimerkiksi kytkemään käsiteltävän asian heidän omiin kokemuksiinsa. Myös käsiteltävän asian työstämistä vaativat lyhyet kirjoittamistehtävät ja näiden kirjoitustehtävien purkaminen pienissä opiskelijaryhmissä, esitelmät, roolileikit yms. menetelmät ovat omiaan stimuloimaan aktiivista oppimista.

Toiseksi opettamiseen liittyy myös monenlaisia käytännön ongelmia, joiden ratkaisemisessa muiden opettajien kokemukset saattavat huomattavasti auttaa. (Näitä kokemuksia ja ideoita on pyritty opaskirjassanikin välittämään.) Tällaista opetusmenetelmiin ja oppimisen 'puitetekijöihin' liittyvää oppimateriaalia on julkaistu ulkomailla runsaasti, mutta maassamme toistaiseksi melko vähän. Sen sijaan oppimisen perusteista on olemassa maassamme melko runsaasti opettajille tarkoitettua kirjallisuutta (esim. Lehtinen ym. 1990; Engeström 1991; Lonka \& Lonka 1991; viimeksi mainittu teos sisältää myös kuvauksia ja esimerkkejä aktivoivista opetusmenetelmistä).

Kolmanneksi käytännönläheisten menetelmien soveltaminen saattaa olla opetuksen kehittämisessä ainakin kasvatustieteen teorioita tuntemattomalle (esim. luonnontieteen opettajalle) luontevaampi ja helpommin toteutettavissa oleva lähestymistapa kuin laajan oppimisteoreettisen kirjallisuuden tai tutkimusperinteen läpikäymien. Kuten minkä tahansa erityisalan, myöskään kasvatustieteen tieteellisten artikkeleiden sisältö ei helpolla avaudu muiden alojen tutkijoille, ikä kasvatustieteelliseen diskurssiin näytä yleensä kuuluvan 'normatiivisten' ohjeiden antamien (ks. Välimaa 1995). Yliopisto-opettajat kuinkin usein odottavat opetuksen kehittelijöiltä käytännönläheisiä ideoita ja ohjeita, joiden pohjalta he voivat kehittää opetustaan. Tähän kysyntään vastatakseen ovat ulkomaiset Yliopisto-opetuksen kehittämiskeskukset tuottaneet runsaasti nimenomaan näihin opetusmenetelmiin liittyvää materiaalia; abstrakteja tieteellisiä artikkeleita ja malleja nämä osastot eivät juurikaan levitä. Tällaisen käytännönläheisen, opettajien opetuskokeiluja esittelevän kirjallisuuden käyttö osoittautui onnistuneeksi linjaksi myös Joensuun yliopiston pedagogisessa kehittämishankkeessa vuosina 1991-1993 (Kekäle \& Kuittinen 1993).

Toisaalta opetuksen kehittämisen eri lähestymistavat eivät välttämättä ole toisiaan poissulkevia vaihtoehtoja; voidaan ajatella, että opetuksen kehittäminen edellyttää sekä (sisäistettyä) käsitystä oppimisen perusteista että myös menetelmiä, joilla opetusta voidaan käytännössä lähteä kehittämään.

\section{Perinteisen luento-opetuksen monipuolistaminen}

Perinteisellä yksisuuntaisella luento-opetuksella (luennoitsija puhuu ja muut kuuntelevat) näyttäisi yleisesti ottaen olevan eräitä kiistattomia vahvuuksia. Näitä ovat esimerkiksi mahdollisuus luennoitsijan innostuksen ja kiinnostuksen (sekä myös välinpitämättömyyden) välittymiseen, mahdollisuus luennon joustavaan rakentamiseen kuulijakunnan tarpeiden mukaiseksi, mahdollisuus välittää informaatiota sadoille, jopa tuhansille kuulijoille, jne. (Cashin 1985; Chistn et.al 1992).

Luentoja on perinteisesti käytetty informaation, faktojen ja yleistysten esittämiseen. Luennon avulla tutkija voi esittää oman näkemyksensä tietystä kysymyksestä siten, että asiasta voidaan vielä keskustella kuulijakunnan kanssa. Luennot voivat olla tarkoituksenmukainen opetusmuoto erityisesti, jos luennoitavaa materiaalia ei ole saatavissa muussa muodossa tai jos luennointi jostain muusta syystä on perusteltua (esim. ajan puute, käsiteltävän asian selventäminen esimerkkien, jäsennysten yms. avulla, opiskelijoiden motivaation heikkous tai tarvittavien valmiuksien ja yleistietojen puute, minkä vuoksi käsiteltävän asian omaehtoinen opiskelu ei ehkä tuottaisi hyviä tuloksia jne.; ks. myös Kekäle \& Kuittinen 1992).

Perinteisellä luento-opetuksella on yleisesti ottaen myös tiettyjä heikkouksia. Opiskelijat eivät opi kaikkia asioita yhtä nopeasti eivätkä he välttämättä ole tiedoiltaan samalla tasolla. Perinteinen luento-opetus jättää opiskelijoiden väliset erot melko pitkälti huomioimatta, kun taas esim. kirjasta asia voidaan lukea moneen kertaan. Palautteen ja vuorovaikutukseen pohjautuvan opetuksen avulla voidaan luennoillakin ainakin jossain määrin huomioida opiskelijoiden välisiä oppimiseroja. 
Toisaalta muutkaan opetusmuodot eivät ole tässä suhteessa ongelmattomia: hyvin yksilöllisen opetuksen toteuttaminen lienee nykyisessä taloudellisessa tilanteessa hankalaa ja opiskelijan täysin itsenäiseen työskentelyynkin liittyy omat riskinsä, jotka todettiin Yhdysvalloissa opetuksen kehittämishankkeissa jo 1950-luvulla (Baez 1976). Täysin itsenäisesti työskennellessä opiskelijoiden väliset oppimiserot ovat usein huomattavia; toiset oppivat tehokkaasti ja toiset taas hyvin vähän. Luento-opetuksen merkittävä etu on se, että paikalla on alaa tunteva opettaja, joka voi parhaan kykynsä mukaan pyrkiä oikaisemaan väärinkäsityksiä, selventää asiaa esimerkein ja ohjata opiskelijoiden oppimisprosessia.

Perinteiset luennot eivät näyttäisi soveltuvan kovin hyvin korkeamman tasoiseen oppimiseen, kuten asian soveltamiseen ja jäsentelyyn, synteesin tai kokonaisnäkemyksen muodostamiseen, asenteisiin ja arvoihin vaikuttamiseen tai motoristen taitojen kehittämiseen. Perinteinen yksisuuntainen luennointi soveltuu yleensä parhaiten tiedon välittämiseen, opetusaiheeseen orientoimiseen, asian pinnallisempaan oppimiseen ja ymmärtämiseen tai käsiteltyjen asioiden kertaamiseen ja systematisointiin (Cashin 1985; Engeström 1991; Gibbs 1992). Mikäli opiskelijoiden kirjoitustaitoja ja kriittistä ajattelua halutaan kehittää, muut opetusmenetelmät saattavat olla luennointia parempia, tai sitten luento-opetukseen tulisi liittää näitä taitoja kehittäviä harjoituksia. Monesti luento tai esittävä opetus onkin tarkoituksenmukaisinta jaksottaa siten, että luennoinnin lomaan järjestetään tehtäviä ja yhteistoiminnallista opetusta (Engeström 1991, 123-125). Seuraavassa on esimerkkejä luennon jaksottamisesta siten, että samalla voidaan tehdä luennosta parempi oppimistilanne ja ylittää joitakin yksisuuntaiselle luento-opetukselle tyypillisiä ongelmia. Näitä ovat mm. seuraavat:

\section{a) Opiskelijoiden tarkkaavaisuus laskee luennolla nopeasti}

Empiiristen tutkimusten mukaan opiskelijoiden keskittyminen laskee yleensä jo noin 15-25 minuutin kuluttua, mikäli opetuksessa käytetään monotonisesti vain yhtä tietolähdettä tai esitystapaa ja tehtävä on vaativa ja korkeamman asteista oppimista edellyttävä (Bligh 1974, 70-71; Gibbs 1988, 105; Andresen 1990, 27). Luennointi saattaa kuitenkin olla tehokasta lyhyinä jaksoina. Koska pitkään luennoitaessa opiskelijoiden huomiokyky alkaa kuitenkin heiketä, tulisi 3-4 tunnin luento jaksotella sopivasti. Esimerkiksi muutaman minuutin kestävä porinaryhmä tai keskustelu käsiteltävään aiheeseen liittyvästä teemasta katkaisee luennoinnin sopivasti ja lisää yleensä oppimistehoa. Tällaisen tauon jälkeen käsiteltävään asiaan keskittyminen on jälleen helpompaa opiskelijoille (ks. Kekäle 1994).

\section{b) Luentoaika kuluu kalvojen kopiointiin}

Yksi perinteisen luento-opetuksen perusongelma on, että opiskelijat pohtivat käsiteltävää asiaa samanaikaisesti, kun he kopioivat kalvoja ja tekevät muistiinpanoja. Nämä tehtävät ovat usein ristiriidassa keskenään; kopioiminen vaikeuttaa ajattelemista ja asian oppimista. Oppimiseen näyttävät tosin vaikuttavan luentomuistiinpanojen kirjoittamisen ohella olennaisesti myös esitysnopeus, kuulijoiden taidot ja kyvyt sekä luonnollisesti myös opiskelijan mielenkiinto käsiteltävää asiaa kohtaan. Nopea etenemisvauhti heikentää opiskelijoiden mahdollisuuksia pohtia itse käsiteltävää asiaa, vaikka toisaalta on myös niin, että niitä harjaantuneempaa opiskelijan muistiinpanojen teko ja kirjoittaminen itsessään on, sitä enemmän jää tilaa muulle tiedon prosessoinnille (Lehtinen ym. 1990, 40).

Opiskelijan tarkkaavaisuus ja ajatukset voi tosin tällöinkin suuntautua joko käsiteltävä asian pohtimiseen, tai asioihin ja kiinnostuksen kohteisiin, jotka eivät lainkaan liity luentoon.

Turhauttavaa ja oppimisen kannalta usein hyödytöntä piirtoheitinkalvojen mekaanista kopiointia ja muistiinpanojen kirjoittamista voi kuitenkin olennaisesti vähentää esimerkiksi jakamalla luentomonisteita tai jaksottamalla luentomuistiinpanojen tekoa. Lonka (1991b, 63) suosittelee kalvojen käytön sijasta esityksen avainsanojen kirjoittamista taululle. Kuulijat voivat poimia olennaiset asiat puheesta, mikä edistää kalvojen kopiointia paremmin tiedon aktiivista prosessointia. Tämän kaltainen käsiteltävää asiaa jäsentävä, aktiivinen ja pohdiskeleva muistiinpanojen teko saattaa olla hyvin hyödyllistä oppimisen kannalta. Muistiinpanojen tekoa, asian aktiivista pohdintaa ja oppimista voidaan luennoilla tukea myös esimerkiksi seuraavan kahden yksinkertaisen menetelmän avulla.

\section{Menetelmä 1.}

Muistiinpanojen tekemisen voi kieltää tiettyä asiakokonaisuutta käsittelevän lyhyen luennointijakson ajaksi. Opiskelijoita kehotetaan tekemään muistiinpanot vasta kunkin lyhyen luennointijakson jälkeen. Menetelmää on käytetty seuraavasti: Ensin noin 15 minuuttia luennointia. Tämän luentojakson tulisi olla selkeä ja hyvin jäsennelty, eikä sen tulisi käsitellä liian monimutkaista asiaa. Tämän jälkeen opiskelijoita pyydetään tekemään muistiinpanot käsitellystä asiasta esimerkiksi kirjoittamalla, listaamalla keskeiset seikat ja piirtämällä kaavioita. Tähän annetaan riittävästi aikaa, yleensä noin 5-10 minuuttia. Ennen seuraavaan teemaan tai asiakokonaisuuteen 
siirtymistä opiskelijoiden annetaan korjata, täydentää ja tarkistaa muistiinpanojaan esimerkiksi kysymällä opettajalta, opettajan esittämistä kalvoista tarkistamalla tai keskustelemalla vierustoverin kanssa (ks. Gibbs, Habeshaw \& Haheshaw 1988, 29; Kekäle 1994),

Menetelmä lisää opiskelijoiden tarkkaavaisuutta luentojakson aikana, sillä opiskelijat tietävät joutuvansa kirjoittamaan muistiinpanot myöhemmin. Lisäksi menetelmä suuntaa asian ymmärtämiseen, ei mekaaniseen kopiointiin, sillä kunnollisten ja tiiviiden muistiinpanojen tekeminen jälkikäteen edellyttää asian olennaisten seikkojen ymmärtämistä. Näin ollen käytäntö on omiaan tehostamaan asian oppimista ja ymmärtämistä luennon aikana. Opettaja voi myös tavallista paremmin arvioida opiskelijoiden oppimisen tasoa tarkastelemalla heidän muistiinpanojaan. Menetelmä saattaa kuitenkin aluksi tuntua opiskelijoista oudolta ja vaikealta. Sen käyttö vaatiikin kunnollista perustelua ja mahdollisuutta tarkistaa, ovatko opiskelijat ymmärtäneet käsiteltävän asian. Luennoinnin yhteydessä esitettävät monimutkaisemmat kuviot tms. olisi hyvä jakaa monisteina opiskelijoille.

\section{Menetelmä 2.}

Toisessa menetelmässä sovelletaan W.F. Hillin ja A. Northedgen ideoita keskustelemalla oppimisesta. Menetelmää voidaan hyödyntää myös suurille ryhmille luennoimiseen, kun siihen yhdistetään strukturoitujen luentomonisteiden jakaminen (Andresen 1990, 8). Opiskelijoille jaetusta luentomonisteesta selviää jo luennon alussa, mitä taitoja tai asioita luennon kuluessa on tarkoitus oppia. Luento koostuu jaksoista, jotka kytkeytyvät tiiviisti esitettyihin päämääriin. jokainen tällainen luennon jakso alkaa aktivoivalla tehtävällä, kuten esimerkiksi yksilöllisellä työllä, pareittain tai pienryhmässä tapahtuvalla keskustelulla tai tehtävällä ja aiheeseen liittyvien ideoiden sekä tietojen kirjaamisella.

Tämän jälkeen asiaa käsitellään yhdessä laajemmin ja annetaan palautetta tai vastauksia esitettyihin kysymyksiin. Opettaja selventää, selittää ja tulkitsee asiaa yksityiskohtia myöten, kunnes asia on riittävän kattavasti käsitelty ja opiskelijat ymmärtävät sen. Seuraavaksi opiskelijoille annetaan aikaa muistiinpanojen tekemiseen luennon (luentomonisteessa mainittujen) päämäärien kannalta keskeisten asioiden osalta. Opiskelijoiden tulee tehdä itselleen yhteenveto siitä, mitä he nyt ymmärtävät asiasta. Seuraava vaihe tai oppimispäämäärä käsitellään samalla tavalla. Kun kaikki luennon vaiheet on käsitelty edellä kuvatulla tavalla, luennoitsija tekee yhteenvedon koko luennosta tai istunnosta ja suhteuttaa yhteenvetonsa luennon alkuperäisiin, luentomonisteessa annettuihin oppimispäämääriin.

Yhden tällaisen luentokerran aikana ei yleensä käsitellä enemmän kuin kolme-neljä keskeistä kohtaa tai teemaa. Tällä rajoituksella on se etu, että se estää opettajaa käsittelemästä liian monta asiaa luennon aikana, joten käsiteltävä asia on paremmin opiskelijoiden omaksuttavissa. Edellä kuvattu menetelmä on osoittautunut arvokkaaksi keinoksi haluttaessa kehittää opiskelijoiden muistiinpanotaitoja.

\section{c) opettaja ei saa luennoilla palautetta}

Usein väitetään, että opettaja ei saa luennoilla palautetta. Luennoitsijat esittävät luennon lopussa tavallisesti kysymyksen: "onko kysyttävää?". Tämä rutiininomainen kysymys saa helposti opiskelijoiden mielissä merkityksen 'Jos kellään ei ole kysyttävää, luento loppuu ja voimme lähteä". Tämän vuoksi kysymyksen esittävä opiskelija saattaa jopa joutua epäsuosioon opiskelijatovereiden piirissä. Bligh (1974, 131) suositteleekin palautteen hankkimista esim. 20-30 minuutin luennoinnin jälkeen, eikä pelkästään luennon lopussa. Opiskelijoille tehtävät palautekysymykset voi myös kohdentaa olennaisiin seikkoihin yleisen "onko kysyttävää?" -kysymyksen sijasta. Palautetta voi hankkia luennon eri vaiheissa: ennen luentoa, luennon aikana, luennon lopussa tai sen jälkeen. Palaute voi olla verbaalista, kielellisessä muodossa esitettyä (puheen, kirjoituksen tai esim. sähköpostin välityksellä), mutta usein opiskelijat viestittävät myös ei-kielellisesti, eleillään ja ilmeillään.

Esimerkiksi alkukoe järjestetään useimmiten ensimmäisellä luentokerralla. Sen tarkoituksena on selvittää osallistujien perustaso ja toimia pohjana kurssin suunnittelulle ja opiskelijoiden loppuarvioinnille. Alkukokeen tulokset kannattaa esittää myös opetusryhmälle ja antaa opiskelijoille vihjeitä siitä, mihin suuntaa heidän tulisi opettajan mukaan kehittyä (Lonka \& Lonka 1991, 29). Alkukokeessa saattaa tulla myös ilmi ajattelumalleja, jotka saattavat estää käsiteltävän asian ymmärtämistä ja oppimista. Näihin seikkoihin opettajan tulisi kiinnittää kurssin aikana erityistä huomiota (Lotika 1991b, 61). Luennon aikana palautteen hankkimiseen voi (oppiaineesta riippuen) käyttää esimerkiksi lyhyitä tietokilpailuja tai monivalintatehtäviä. Opiskelijoiden oppimisvaikeuksia voidaan kartoittaa ja tunnistaa pian niiden ilmaantumisen jälkeen myös seuraavilla tavoilla (ks. myös Andresen 1990; Gibbs, Habeshaw \& Habeshaw 1988; Gibbs 1992; Stanley 1991). Luennoitsija kirjoittaa taululle ennen luennon alkua toisen kohtien 1 ja 2 vaihtoehtoisista kysymyksistä:

1. Mikä oli tärkein asia, jonka opit tänään? tai Luennon kolme tärkeintä seikkaa olivat...

2. Mikä kysymys on päällimmäisenä mielessäsi luennon jälkeen tai Luennon vaikein teema? 
Luennoitsija selittää, että luennon lopussa opiskelijoiden tulee kirjoittaa lyhyt vastaus taululla esitettyihin kysymyksiin. Opiskelijoita pyydetään kirjoittamaan vastauksensa muutamaa minuuttia ennen luennon loppua. Luennoitsija kerää paperit ja lukee ne myöhemmin. Tämä mahdollistaa opiskelijoiden luentojen sisältöä koskevien väärinkäsitysten havaitsemisen ja oikaisun varhaisessa vaiheessa. Opettaja voi myös lyhyesti selittää nämä keskeiset seikat parin minuutin vastausajan jälkeen. Samalla hänen tulisi perustella, miksi kyseiset seikat ovat olennaisimpia tai vaikeita. Opettaja voi myös kysyä opiskelijoilta montako keskeistä seikkaa he pystyivät nimeämään ja mitä muita seikkoja opiskelijat pitivät tärkeinä. Menetelmä lisää myös opiskelijoiden kuunteluaktiivisuutta luennon aikana, sillä he tietävät, että luennon lopussa on tehtävänä kirjoittaa käsiteltävästä asiasta.

\section{d) Opiskelijat ovat passiivisia}

Usein todetaan, että opiskelijat ovat passiivisia luennoilla. On kuitenkin huomattava, että se ettei opiskelijoissa juuri näy ulkoista aktiivisuutta ei ole välttämättä sama asia kuin se, että opiskelijat eivät ajattele käsiteltävää asiaa. Engeströmin (1991) mukaan luennon ja esittävän opetuksen leimaaminen 'passivoiviksi' opetusmenetelmiksi osoittaa, ettei ole ymmärretty ihmisen henkisen, sisäisen aktiivisuuden ratkaisevaa merkitystä oppimisessa. Hyvin suunniteltu luento edellyttää kuulijoilta monipuolista ja intensiivistä henkistä toimintaa (Engeström 1991).

Opiskelijoiden henkistä aktiivisuutta voidaan stimuloida luennon lomassa annettavilla aktivoivilla tehtävillä, joista on jo edellä annettu joitakin esimerkkejä. Myös erilaiset 'ennakkojäsentäjät' voivat toimia aktivoivana tehtävänä.

Ennakkojäsentäjän tehtävä on kytkeä uusi asia opiskelijoiden aikaisempaan tietämykseen. Ennakkojäsentäjällä tarkoitetaan asian aktivoimista opiskelijoiden mielissä ennen sen opettamista, niin että uusi tieto kytkeytyy vanhaan helpommin. Opetettavat asiat tulevat merkityksellisiksi ja ne opitaan paremmin, kun ne liitetään oikeaan asiayhteyteen. Tällaisia tehtäviä voivat olla asian pohdintaa virittävät kysymykset, aktivoivat kirjoitustehtävät, alkukoe, luonnosteleva kirjoittaminen, ongelmien määrittely tai tietopohjan jakaminen (ks. Lonka \& Lonka 1991, 30. Esimerkiksi Darwinin teoriaa käsittelevä luento voi alkaa opiskelijoiden keskinäisillä luonnonvalintaa käsittelevillä keskusteluilla, jolloin tämä keskustelu toimii ennakkojäsentäjänä (Gibbs, Habeshaw \& Habeshaw 1988, 69). Opiskelijoita voidaan myös pyytää kirjaamaan nopeasti ylös kaikki, mitä he tietävät alkavan luennon teemasta (Lonka \& Lonka 1991).

\section{Lopuksi}

Edellä on esitetty joitakin yleisiä luento-opetuksen ongeh-nia. Luento-opetus voi kuitenkin toteutua hyvin monella tavalla, joten on yksinkertaistavaa leimata luennointi sinänsä tehottomaksi tai passivoivaksi. Hyvin vedetty monipuolinen luento, johon mahdollisesti sisältyy aktivoivaa opetusta on yhäkin vakavasti otettava opetusmenetelmä. Monet perinteisen luento-opetuksen ongelmat ovat lisäksi melko helposti ylitettävissä (ks. Kekäle 1994). Perinteiseen luento-opetukseen voidaan myös joustavasti sisällyttää harjoituksia, keskustelua tai tehtäviä. Näin voidaan tarjota opetusta, joka on tavallaan välimuoto perinteisen luento-opetuksen ja opiskelijan täysin itsenäisen työskentelyn välillä, ja jossa yhdistyvät eri opetusmuotojen hyvät puolet.

Opetuksen kehittämiseen tarkoitettuja menetelmiä ei kuitenkaan tule soveltaa mekaanisesti, vaan opettajan tulisi aina pohtia niiden soveltuvuutta suhteessa siihen opetustehtävään, johon kulloinkin pyritään. Eri opettajat voivat opetuksen kehittämistyössä päätyä erilaisiin ratkaisuihin, sillä optimaalinen' opetus riippuu paljolti myös opetettavasta aineesta, opettajan ja opiskelijoiden intresseistä ja persoonallisuuksista. Ratkaisu, joka osoittautuu toimivaksi yhden opettajan opetuksessa, ei välttämättä toimikaan toisella opettajalla. Saattaa myös olla, että aikanaan toimiviksi osoittautuneita ratkaisuja joudutaan myöhemmin muuttamaan ja tarkistamaan esimerkiksi uuden opiskelijapolven kohdalla.

Soveltaessaan esitettyjä ideoita käytäntöön opettajan tulisikin hankkia palautetta niiden toimivuudesta. Näin toteutetusta opetuksen kehittämisestä tulee parhaimmillaan itseään korjaava prosessi, jossa kokeillaan perusteltuja ratkaisuja, ja jossa opiskelijoilta saadun palautteen sekä oppimistavoitteiden saavuttamisen perusteella vallitsevia käytäntöjä ja opetusta korjataan, tarkistetaan ja kehitetään asteittain.

\section{LÄHTEET}

Andresen, L. W. 1990. Lecturing to Large Groups. A Guide to Doing it Less .. but BetterProfessional Development Center The University of New South Wales, Australia.

Baez, A.. V. 1976. Innovation in Science Education - Worldwide. Unesco Press Paris.

Bligb, D. A.. 1974. What's the Use of Lectures? Penguin Books. Baskerville. 
Bonwell, G.C. \& Eison, J.A.. 1991. Active Learning. Creating Excitement in the Classroom. ASILE-ERIC Higher Education Report No. 1. The George Washington University. Washington.

Casbin, W.E. 1985. improving Lectures. Idea Paper No. 14. Centerfor Faculty Evaluation \& Development, Kansas State University.

Cbism, N . et.al. 1992. Teaching at Ohio State University: A Handbook. Center for Teaching Excellence. The Ohio State University.

Engeström, Y. 1991. Perustietoa opetuksesta. Valtion Painatuskeskus. Helsinki.

Gibbs, G. \& Habesbaw, T. 1988. 253 Ideas For Your Teaching. Technical and Educational Services Ltd. Bristol.

Gibbs, G. Habesbaw, S. \& Habesbaw, T. 1988. 53 Interesting Things to do in Your Lectures. Technical \& Educational Services Ltd. Bristol.

Gibbs, G. 1992. Lecturing to more Students. Teaching More Students 2. The Polytechnics \& Colleges Funding Council. Oxford.

Karjalainen, A.. \& Kemppainen, T. 1994. Vaihtoehtoisia tenttikäytäntöjä. Korkeakoulupedagogiikan perusmateriaaliprojekti. OPM. Oulun yliopisto.

Kekäle, J. 1994 Luento-opetuksen kehittäminen. Vähemmällä luennoimisella parempiin tuloksiin. Korkeakoulupedagogiikan perusmateriaaliprojekti. OPM. Oulun yliopisto.

Kekäle, J. \& Kuittinen, M. 1992. Miten luento-opetusta tulisi kehittää? Korkeakoulutieto 19 (2), 49-52.

Kekäle, J. \& Kuittinen, M. 1993. Joensuun yliopiston pedagoginen kehittämishanke 1991-92. Hankkeen loppuraportti. JOPKE. Joensuun yliopisto.

Kuittinen, M.. 1994.Mitä luennoinnin sijaan? Malleja opiskelijan itsenäisen työskentelyn lisäämiseksi. Korkeakoulupedagogiikan perusmateriaaliprojekti. OPM. Oulun yliopisto.

Lehtinen, E., Kinnunen, R.., Vauras, M.., Salonen, P., Olkinuora, E., \& Poskiparta, E. 1990. Oppimiskäsitys koulun kehittämisessä. Kouluhallitus. Helsinki.

Lonka, K.. 1991a. Aktivoivan opetuksen pääperiaatteet Teoksessa Lonka, K.. \& Lonka, I. (toim.) Aktivoiva opetus. Käsikiila aikuisten ja nuorten opettajille. Kirjayhtymä. Helsinki.

Lonka, K.. 1991b. Aktivoiva luento tai oppitunti. Teoksessa Lonka, K.. \& Lonka, I.. (toim.) Aktivoiva opetus. Käsikirja aikuisten ja nuorten opettajille. Kirjayhtymä. Helsinki.

Lonka, K.. \& Lonka, I. 1991. Aktivoiva opetus. Käsikirja aikuisten ja nuorten opettajille. Kirjayhtymä- Helsinki.

Marton, F., Dahlgren, L..O., Svensson, L. \& Säljö, R.. 1989. Oppimisen ohjaaminen. Weilin+Göös. Espoo.

Stanley, C.A. 1991. Ed. Bright Ideas in Teaching. Center for Teaching Excellence, The Ohio State University.

Välimaa, J. 1995. Ei ole vain yhtä oikeaa tapaa opettaa jyväskylän yliopiston tiedotuslehti Tiedonjyvä 30 (4), 15 